\title{
Herbicide options for managing competitive vegetation during the establishment of Pinus radiata and Pseudotsuga menziesii var. menziesii in Southland, New Zealand
}

\author{
Carol A. Rolando ${ }^{1 *}$, Michael S. Watt ${ }^{2}$, Christine Todoroki ${ }^{1}$, David Henley ${ }^{2}$ and Alan Leckie $^{2}$
}

\begin{abstract}
Background: Control of weeds is important for survival, growth and uniformity of planted conifers, such as Pinus radiata D.Don and Pseudotsuga mensiesii var. menziesii (Mirb.) Franco. Despite pressure to find environmentally benign herbicides for these species, little research has identified non-residual herbicides that are cost-effective and result in minimal growth loss compared to those used operationally. The objective of this study was to compare efficacy and cost of current operational practice to a range of alternative herbicide treatments for the establishment of these two species using data from two trials located at the same site.

Methods: Treatments for each species were applied in both the first and second year following planting and included weed-free controls, operational practice using terbuthylazine and hexazinone (applied as both spot treatment and broadcast application) and a range of treatments consisting of combinations of clopyralid, triclopyr and haloxyfop (CTH), applied with or without oversowing with less competitive grasses and annual herbaceous species. Application of glyphosate during winter was included within the Pseudotsuga mensiesii trial as a first year treatment only and as a second year treatment following spot application of CTH in the first year.
\end{abstract}

Results: For the Pinus radiata trial, broadcast application of CTH in spring of years 1 and 2 was most effective, with mean stand volume $\left(\mathrm{m}^{3} \mathrm{ha}^{-1}\right)$, at 2.5 years, exceeding the weed-free control and operational treatment by 8 and $11 \%$, respectively, although these differences were not statistically significant at the $5 \%$ level. Use of the operational treatment as a spot in the first year, followed by broadcast application of CTH in the second year, was moderately effective when used with or without oversowing. For the Pseudotsuga mensiesii trial, the four most effective treatments were the operational treatment, broadcast application of CTH during year 1 (CTH-Dec), broadcast application of CTH during spring of years 1 and 2, and broadcast application of glyphosate during winter (winter glyphosate). Although not significantly different, at 2.5 years mean stand volumes in these treatments were on average 24, 29, 33 and 35\% lower than the weed-free control, respectively. Both CTH-Dec and winter glyphosate were less expensive than the operational treatment.

Conclusions: These results highlight potential treatments to either replace terbuthylazine and hexazinone, or reduce their use during establishment weed control for Pinus radiata and Pseudotsuga menziesii, notably for sites dominated by Cytisus scoparius L. (Scotch broom).

Keywords: Herbicides, Oversowing, Radiata pine, Weed control, Certification, Forest stewardship council

\footnotetext{
* Correspondence: carol.rolando@scionresearch.com

'Scion, PO Box 3020, Rotorua, New Zealand

Full list of author information is available at the end of the article
} 


\section{Background}

One of the most critical components of the forest product lifecycle is the economic and environmentally sustainable establishment of commercial forests (Campbell et al. 2013). It is well known that the management of competing vegetation, or weeds, during this establishment phase underpins long-term forest productivity, ensuring good tree survival, optimal growth and stand uniformity at canopy closure (Wagner et al. 2006). For planted forests, managed for commercial production of timber, herbicides provide the most cost-effective means to achieve optimum control of weeds during this establishment phase (Mendell et al. 2015; Neary and Michael 1996; Rolando et al. 2010). Herbicides have been available to forest growers for over 40 years, and their use and application for weed control has been well documented across most forest-growing regions (Little and Rolando 2002; McCarthy et al. 2011; Rolando et al. 2013; Thompson and Pitt 2003). In addition, the optimal, and most costeffective, strategy for managing weeds using herbicides is well known for many regions and embedded in local operational practice (Harrington et al. 1995; Rolando et al. 2013; Rolando and Little 2009). Therefore, factors driving further research into new methods of operational forest weed control are largely related to the availability of more environmentally safe herbicides that have the ability to replace current active ingredients or innovative methods able to reduce the dependence on herbicides whilst retaining current levels of productivity at low cost. The shift to reduce dependence on herbicides for forest weed control has been driven by an increasing global awareness of the impacts of pesticides on the wider environment and human health (Baillie 2016; Garrett et al. 2016; Harrington et al. 1995; Little et al. 2006; Rolando et al. 2013; Rolando and Little 2009; Thiffault and Roy 2011; Wagner et al. 1998). For the forest industry, this shift was supported by the emergence of forest certification in the late 1990s. Established mainly to reduce trade in illegally logged timber, these certification schemes also aim to provide consumers with assurance that wood products are obtained from sustainably managed forests. The result has been a continued requirement for forest growers to revisit their operational weed management programmes to ensure that the use of herbicides also result in minimum impacts to the forest environment whilst remaining cost-effective.

Decades of research have been dedicated to reducing the dependence on herbicides for weed control in New Zealand planted forests (Richardson 1993; Richardson et al. 1996a; Richardson et al. 1996b; Rolando et al. 2010). Over the period 2007 to 2015, much of this research was focused on finding suitable alternatives to or reducing the use of the widely used, and highly effective, active ingredients terbuthylazine ${ }^{1}$ and hexazinone ${ }^{1}$ (Rolando et al. 2011; Rolando and Watt 2014; Watson et al. 2010; Watt et al. 2010; Watt and Rolando 2014; Tran et al. 2015). Between 2007 and 2015, these active ingredients were listed as "highly hazardous" by the Forest Stewardship Council (FSC) and could not be used on FSC-certified forest land without derogation (Forest Stewardship Council 2007, 2015). Since over 50\% of the New Zealand forest industry was certified by FSC (Forest Owners Association 2014), this was a significant issue for growers needing to manage a suite of highly competitive and vigorous weeds with the ability to cause complete crop failure if not adequately managed (Richardson 1991). As a consequence, much research was conducted into the potential for registered herbicides, other than terbuthylazine and hexazinone, to control the suite of weeds common to New Zealand planted forests. The research focused on herbicides that would be effective against the most competitive weeds common to New Zealand forests, that being the scrub weeds Cytisus scoparius L. (Scotch broom) and Ulex europaeus L. (gorse), along with other species such as Buddleia davidii Franch. (Buddleja), Rubus fruticosus L. (blackberry) and Cortaderia selloana (Schult. \& Schult.f.) Asch. \& Graebn (pampas grass). Herbicides that were included in the testing phase included triclopyr ${ }^{1}$, clopyralid $^{1}$, haloxyfop ${ }^{1}$, picloram $^{1}$, indaziflam $^{1}$, nicosulfuran $^{1}$, and mesotrione ${ }^{1}$.

The FSC criteria for rating of herbicides as highly hazardous changed in 2015. This change led to the removal of terbuthylazine and hexazinone from the FSC list of highly hazardous pesticides (HHP). This was a positive outcome for many growers. However, another widely used herbicide, picloram, was added to the list (Forest Stewardship Council 2015). Picloram is used to manage scrub weeds such as $C$. scoparius and $U$. europaeus so there is a need to find alternatives. There is continued interest in New Zealand in the potential of non-residual herbicides for effective forest weed control because of the generally dynamic nature of pesticide regulations globally at present. This interest is partly attributed to the requirement for certified forest growers to continually strive to reduce dependence on the use of herbicides for weed control.

Field trials were implemented at Canterbury and Marlborough, New Zealand, in 2008 to investigate whether the active ingredients clopyralid, triclopyr and picloram could replace terbuthylazine and hexazinone for the control of dense infestations of $C$. scoparius in young Pinus radiata D.Don (radiata pine) stands (Watt and Rolando 2014). These two trials incorporated treatments that tested the impact of herbicide rate and timing of application on herbicide efficacy. The results from these trials indicated that $C$. scoparius could be controlled effectively by the aerial application of $1125 \mathrm{~g} \mathrm{ha}^{-1}$ clopyralid, $113 \mathrm{~g} \mathrm{ha}^{-1}$ triclopyr and $37.5 \mathrm{~g} \mathrm{ha}^{-1}$ picloram in spring (October) in the year of planting, and the year following. The results of 
these two trials also indicated that this combination of active ingredients resulted in a shift in vegetation cover from highly competitive C. scoparius to less competitive grasses and annual herbaceous species, an outcome with potentially positive impacts for stand access required later in the rotation for tending and pruning operations.

To confirm the earlier results on the potential for triclopyr and clopyralid to manage C. scoparius in young Pinus radiata stands, a new trial was implemented on a site dominated by C. scoparius in Southland, New Zealand, during 2011. A separate trial at the same Southland site involved Pseudotsuga menziesii var. menziesii (Mirb.) Franco, as this species is important to the Southland region (New Zealand Institute of Economic Research 2015). Very little research has been conducted on the impact of alternative herbicide treatments on the establishment of this species. As Pseudotsuga menziesii is more sensitive to most commonly used forestry herbicides than Pinus radiata, there is a limited range of alternative herbicides available that are not phytotoxic to this tree species (Maclaren 2008). In addition, Pseudotsuga menziesii is particularly susceptible/sensitive to weed competition which in combination with its slow initial growth, means that good weed control is necessary for a longer duration (Maclaren 2008). Picloram was not included in any treatments in either trial to determine whether efficacy on C. scoparius was retained when this active ingredient was not included in the mix.

The efficacy of clopyralid, triclopyr and haloxyfop, applied in various combinations, was tested for weed control in establishing Pinus radiata or Pseudotsuga menziesii var. menziesii (Douglas-fir) stands. The cost-effectiveness of the different management regimes tested was also evaluated. Oversowing with grasses and annual herbaceous species that are less competitive weeds than C. scoparius was also included in the treatment subset to determine the impact of this procedure on regeneration of this species when used in combination with selected alternative herbicides.

\section{Methods}

Trial location and site description

The Pinus radiata and Pseudotsuga menziesii trials were each located at Rowallan Forest (Compartment 411, Stand 3) (2097875 E and 5450611 N), Southland. This site has a mean annual rainfall of $1232 \mathrm{~mm}$ and a mean annual temperature of $9.5^{\circ} \mathrm{C}$ (New Zealand Meteorological Service 1983) and has relatively low productivity (Site Index (20 years) of $18 \mathrm{~m}$ ) compared to other planted Pinus radiata forest areas within New Zealand (average Site Index (20 years) of $29.9 \mathrm{~m}$; (Watt, et al. 2010)).

The trial areas were planted either with Pinus radiata or Pseudotsuga menziesii in July 2011 at 1000 stems ha $^{-1}$. Site preparation included windrowing and line-ripping in November 2010, followed by an aerial pre-plant spray operation in April 2011 consisting of $2.5 \mathrm{~kg} \mathrm{ha}^{-1}$ glyphosate (AGPRO
Green Glyphosate 510, $510 \mathrm{~g} \mathrm{~L}^{-1}$ glyphosate as the isopropylamine salt, AGPRO NZ Ltd) applied in $100 \mathrm{~L} \mathrm{ha}^{-1}$ water with $0.5 \mathrm{~L} \mathrm{ha}^{-1}$ organosilicone adjuvant. In the oversowing treatment plots and following the pre-plant spray, Holcus lanatus L. (Yorkshire fog grass) was sown at $5.0 \mathrm{~kg} \mathrm{ha}^{-1}$, together with a mix of Lolium perenne L. and Trifolium repens L. (rye/clover mix) at $8.0 \mathrm{~kg} \mathrm{ha}^{-1}$. In May 2011, all plots other than those that were oversown, received a second preplant spray with $0.8 \mathrm{~kg} \mathrm{ha}^{-1}$ glyphosate and $0.18 \mathrm{~kg} \mathrm{ha}^{-1}$ triclopyr (AGPRO Triclop 600, $600 \mathrm{~g} \mathrm{~L}^{-1}$ triclopyr as the butoxyethyl ester; AGPRO NZ Ltd) applied in $100 \mathrm{~L} \mathrm{ha}^{-1}$ water with $0.3 \mathrm{~L} \mathrm{ha}^{-1}$ organosilicone adjuvant.

Both trials consisted of four replications of 12 treatments assigned in a completely randomised design. The trials included the following treatments, with minor variations to suit the planted species (see Tables 1 and 2 for details of treatments):

- Two control treatments, one which included no weed control (treatment 1: no control) and one which included complete weed control (treatment 2: weedfree). These controls provided reference data for determining the potential growth of trees relative to weed competition (particularly C. scoparius) at the site.

- An operational treatment (treatment 3: operational) that reflected the forest company's standard operational practice for the site. This treatment served to benchmark the performance of the alternatives relative to the current operational practice. For the first year aerial release operation, terbuthylazine alone was used in the Pseudotsuga menziesii trial but a mixture of terbuthylazine and hexazinone was used in the Pinus radiata trial. Control in the second year consisted of an aerial application of a clopyralid and triclopyr mix to both trials.

- Spot control treatments with terbuthylazine only (Pseudotsuga menziesii trial), or terbuthylazine and hexazinone (Pinus radiata trial) that either did not (treatment 4: spot control 1) or did (treatment 5: spot control 2) include follow-up control in the second year following planting. Spot control provides a reduction in the area that required weeding as well as the amount of active ingredient applied to the site.

- The broadcast application of a mixture containing clopyralid (C), triclopyr (T) and haloxyfop $(\mathrm{H})$ in the first year release operation (October or December), with or without follow-up weed control (spraying) in the second year after planting (treatments 6-9: CTH-Oct x2; CTH-Oct; CTH-Decx2; CTH-Dec). These treatments were included to test herbicide alternatives to terbuthylazine and hexazinone.

- Spot-control treatments that were carried out in conjunction with an oversowing operation 
Table 1 Treatments applied in the Pinus radiata trial showing active ingredients $\left(\mathrm{a} . \mathrm{i} . \mathrm{g} \mathrm{ha}^{-1}\right.$ ). All herbicides were applied to the entire plot, apart from the spot applications treatments indicated in bold. All herbicides were applied with water to make up $200 \mathrm{~L}$ $\mathrm{ha}^{-1}$. Treatments marked with an asterisk were oversown. Amount of active ingredient used for spot control was based on planting density of 1000 stems per hectare. Products used are shown below the table

\begin{tabular}{|c|c|c|c|c|}
\hline \multirow[t]{2}{*}{ No. } & \multirow[t]{2}{*}{ Treatment } & \multirow[t]{2}{*}{ Timing } & \multicolumn{2}{|l|}{ Year applied } \\
\hline & & & Year 1 (after planting) & Year 2 \\
\hline 1 & No Control & - & & \\
\hline 2 & Weedfree & Ongoing & $\begin{array}{l}7500 \mathrm{~g} \mathrm{ha}^{-1} \text { a terbuthylazine @, } 1800 \mathrm{~g} \mathrm{ha}^{-1} \\
\text { hexazinone, applied as and when needed. }\end{array}$ & $\begin{array}{l}7500 \mathrm{~g} \mathrm{ha}^{-1} \text { a terbuthylazine, } 1800 \mathrm{~g} \mathrm{ha}^{-1} \\
\text { hexazinone applied as and when needed. }\end{array}$ \\
\hline 3 & Operational & Oct & $8000 \mathrm{~g} \mathrm{ha}^{-1}$ aterbuthylazine, $2000 \mathrm{~g} \mathrm{ha}^{-1}$ hexazinone. & $\begin{array}{l}\text { b } 1500 \mathrm{~g} \text { clopyralid, } 300 \mathrm{~g} \mathrm{ha}^{-1} \text { ctriclopyr, } \\
\text { organosilicone adjuvant applied in October. }\end{array}$ \\
\hline 4 & Spot Control (1) & Oct & $\begin{array}{l}1.4 \text { diameter spot } 1200 \mathrm{~g} \mathrm{ha}^{-1} \text { aterbuthylazine, } \\
300 \mathrm{~g} \mathrm{ha}^{-1} \text { hexazinone }\end{array}$ & No weed control \\
\hline 5 & Spot Control (2) & Oct & $\begin{array}{l}1.4 \text { diameter spot } 1200 \mathrm{~g} \mathrm{ha}^{-1} \text { aterbuthylazine, } \\
300 \mathrm{~g} \mathrm{ha}^{-1} \text { hexazinone }\end{array}$ & $\begin{array}{l}1500 \mathrm{~g} \mathrm{ha}^{-1} \text { b clopyralid; } 300 \mathrm{~g} \mathrm{ha}^{-1} c_{\text {triclopyr, }} \\
150 \mathrm{~g} \mathrm{ha}^{-1}{ }_{\text {dhaloxyfop, organosilicone adjuvant }} \\
\text { applied Oct. }\end{array}$ \\
\hline 6 & CTH-Oct $x 2$ & Oct & $\begin{array}{l}1125 \mathrm{~g} \mathrm{ha}^{-1} \text { b clopyralid, } 225 \mathrm{~g} \mathrm{ha}^{-1} c_{\text {triclopyr, }} \\
150 \mathrm{~g} \mathrm{ha}^{-1} \text {, }{ }^{\mathrm{d}} \text { haloxyfop, organosilicone adjuvant }\end{array}$ & Repeat first year, applied Oct. \\
\hline 7 & $\mathrm{CTH}-\mathrm{Oct}$ & Oct & $\begin{array}{l}1125 \mathrm{~g} \mathrm{ha}^{-1} \text { b clopyralid, } 225 \mathrm{~g} \mathrm{ha}^{-1} \text { ctriclopyr, } \\
150 \mathrm{~g} \mathrm{ha}^{-1} \text { haloxyfop, organosilicone adjuvant }\end{array}$ & No weed control. \\
\hline 8 & CTH-Dec $\times 2$ & Dec & $\begin{array}{l}1125 \mathrm{~g} \mathrm{ha}^{-1} \text { b clopyralid, } 225 \mathrm{~g} \mathrm{ha}^{-1} c_{\text {triclopyr, }} \\
150 \mathrm{~g} \mathrm{ha}^{-1} \text { haloxyfop, organosilicone adjuvant }\end{array}$ & Repeat first year, applied Dec. \\
\hline 9 & CTH-Dec & Dec & $\begin{array}{l}1125 \mathrm{~g} \mathrm{ha}^{-1} \text { b }{ }^{2} \text { lopyralid, } 225 \mathrm{~g} \mathrm{ha}^{-1} \text { ctriclopyr, } \\
150 \mathrm{~g} \mathrm{ha}^{-1} \text { haloxyfop, organosilicone adjuvant }\end{array}$ & No weed control. \\
\hline $10^{*}$ & Spot Control (3) & Oct & $\begin{array}{l}1.4 \text { diameter spot } 175 \mathrm{~g} \mathrm{ha}^{-1} \text { bclopyralid, } \\
35 \mathrm{~g} \mathrm{ha}^{-1} c_{\text {triclopyr, organosilicone adjuvant }}\end{array}$ & No weed control \\
\hline $11^{*}$ & Spot Control (4) & Oct & $\begin{array}{l}1.4 \text { diameter spot } 175 \mathrm{~g} \mathrm{ha}^{-1} \text { b clopyralid, } \\
35 \mathrm{~g} \mathrm{ha}^{-1} c_{\text {triclopyr, organosilicone adjuvant }}\end{array}$ & $\begin{array}{l}1500 \mathrm{~g} \mathrm{ha}^{-1} \text { b clopyralid, } 300 \mathrm{~g} \mathrm{ha}^{-1} \text { ctriclopyr, } \\
\text { organosilicone adjuvant applied Oct. }\end{array}$ \\
\hline $12^{*}$ & Spot Control (5) & Oct & $\begin{array}{l}1.4 \text { diameter spot } 1200 \mathrm{~g} \mathrm{ha}^{-1} \text { aterbuthylazine, } \\
300 \mathrm{~g} \mathrm{ha}^{-1} \text { hexazinone, organosilicone adjuvant }\end{array}$ & $\begin{array}{l}1500 \mathrm{~g} \mathrm{ha}^{-1} \text { b} \text { clopyralid, } 300 \mathrm{~g} \mathrm{ha}^{-1} c_{\text {triclopyr, }} \\
\text { organosilicone adjuvant applied Oct. }\end{array}$ \\
\hline
\end{tabular}

${ }^{\mathrm{a} A G P R O}$ Valzine Extra, $400 \mathrm{~g} \mathrm{~L}^{-1}$ terbuthylazine and $100 \mathrm{~g} \mathrm{~L}^{-1}$ hexazinone, AGPRO NZ Ltd

bersatill, $300 \mathrm{~g} \mathrm{~L}^{-1}$ clopyralid, DOW AgroSciences NZ

'Grazon, $600 \mathrm{~g} \mathrm{~L}^{-1}$ triclopyr, DOW AgroSciences NZ

dGallant, $100 \mathrm{~g} \mathrm{~L}^{-1}$ haloxyfop P-methyl, DOW AgroSciences NZ

(treatments 10-12 Pinus radiata trial only: spot control 3, 4 and 5). These treatments were implemented to better understand the impact of oversowing on the regrowth of the scrub weeds such as C. scoparius.

- Treatments that included a broadcast application of glyphosate in the winter following planting, either without a second year release operation (treatment 10: winter glyphosate), or with a second year release operation (treatment 11: CHT-Oct and winter glyphosate). These treatments were tested in the Pseudotsuga menziesii trial only.

Each treatment plot included 10 trees (two rows of five trees) with a buffer of two rows between adjacent plots. Herbicides were applied to the inner 10 trees. For the Pinus radiata trial, all treatments, except treatments 8 and 9, were applied in mid-October 2011 or 2012. Treatments 8 and 9 were applied on 6 December 2011. The same methods were used for the Pseudotsuga menziesii trial, with the exception of treatments 10 and 11 which were applied in late July 2012. All treatments were applied manually using a Solo Knapsack sprayer calibrated to deliver $200 \mathrm{~L} \mathrm{ha}^{-1}$.

\section{Measurements and assessments}

Measurements of tree height (ht) and groundline diameter (gld) were taken before treatment application, and at approximately $3,6,12,18$ and 30 (2.5 years) months after trial initiation. Measurements commenced in October 2011 prior to application of the first (post-planting) herbicide treatments and were completed by 30 April 2014. Measurements of ht and gld were used to calculate tree volume, $V$, using the formula of a parabolic cone, Eq. 1. The formula is directly proportional to a derived biomass index, BI (defined as the product of the square of groundline diameter and tree height, i.e. $\mathrm{BI}=\mathrm{gld}^{2} . \mathrm{ht}$ ) which was found to be closely correlated with aboveground biomass (Eccles et al. 1997). Therefore, $V$ will also be closely correlated with above-ground biomass, and application of standard least squares techniques with either $V$ or $\mathrm{BI}$ as the response variable will result in identical significance levels for the treatments. 
Table 2 Treatments applied in Pseudotsuga menziesii trial showing active ingredients (a.i. $\mathrm{g} \mathrm{ha}{ }^{-1}$ ). All herbicides are applied to the entire plot, apart from the spot applications indicated in bold. All herbicides are applied with water to make up $200 \mathrm{~L}$ ha ${ }^{-1}$. The treatment where oversowing was applied is marked with an asterisk. Amount of active ingredient used for spot control was based on planting density of 1000 stems per hectare. Products used are shown below the table

\begin{tabular}{|c|c|c|c|c|}
\hline \multirow[t]{2}{*}{ No. } & \multirow[t]{2}{*}{ Treatment } & \multirow[t]{2}{*}{ Timing } & \multicolumn{2}{|l|}{ Year applied } \\
\hline & & & Year 1 (after planting) & Year 2 \\
\hline 1 & No Control & - & No weed control & No weed control \\
\hline 2 & Weedfree & Ongoing & $\begin{array}{l}10000 \mathrm{~g} \mathrm{ha}^{-1} \text { aterbuthylazine, } \\
\text { applied as and when needed }\end{array}$ & $\begin{array}{l}10000 \mathrm{~g} \mathrm{ha}^{-1}{ }^{a} \text { terbuthylazine, applied as } \\
\text { and when needed }\end{array}$ \\
\hline 3 & Operational & Oct & $\begin{array}{l}10000 \mathrm{~g} \mathrm{ha}^{-1} \text { a terbuthylazine, } 150 \mathrm{~g} \\
\text { ha }^{-1} \text { dhaloxyfop }\end{array}$ & $\begin{array}{l}1500 \mathrm{~g} \mathrm{ha}^{-1} \text { b clopyralid and organosilicone } \\
\text { adjuvant applied in October. }\end{array}$ \\
\hline 4 & Spot Control (1) & Oct & $\begin{array}{l}1.4 \text { diameter spot } 10000 \mathrm{~g} \mathrm{ha}^{-1} \text { aterbuthylazine, } \\
150 \mathrm{~g} \mathrm{ha}^{-1} \text { haloxyfop }\end{array}$ & No weed control \\
\hline 5 & Spot Control (2) & Oct & $\begin{array}{l}1.4 \text { diameter spot } 10000 \mathrm{~g} \mathrm{ha}^{-1} \text { aterbuthylazine, } \\
150 \mathrm{~g} \mathrm{ha}^{-1} \text { haloxyfop }\end{array}$ & $\begin{array}{l}1500 \mathrm{~g} \mathrm{ha}^{-1} \text { b clopyralid; } 300 \mathrm{~g} \mathrm{ha}^{-1} \text { ctriclopyr, } 150 \mathrm{~g} \mathrm{ha}^{-1} \\
\text { dhaloxyfop, organosilicone adjuvant applied Oct. }\end{array}$ \\
\hline 6 & CTH-Oct $\times 2$ & Oct & $\begin{array}{l}1125 \mathrm{~g} \mathrm{ha}^{-1} \text { b clopyralid, } 225 \mathrm{~g} \mathrm{ha}^{-1} \text { ctriclopyr, } \\
150 \mathrm{~g} \mathrm{ha}^{-1} \text { haloxyfop, organosilicone adjuvant }\end{array}$ & Repeat first year, applied Oct. \\
\hline 7 & $\mathrm{CTH}-\mathrm{Oct}$ & Oct & $\begin{array}{l}1125 \mathrm{~g} \mathrm{ha}^{-1} \text { b clopyralid, } 225 \mathrm{~g} \mathrm{ha}^{-1} c_{\text {triclopyr, }} \\
150 \mathrm{~g} \mathrm{ha}^{-1} \text { haloxyfop, organosilicone adjuvant }\end{array}$ & No weed control. \\
\hline 8 & CTH-Decx2 & Dec & $\begin{array}{l}1125 \mathrm{~g} \mathrm{ha}^{-1} \text { b clopyralid, } 225 \mathrm{~g} \mathrm{ha}^{-1} \text { ctriclopyr, } \\
150 \mathrm{~g} \mathrm{ha}^{-1} \text { dhaloxyfop, organosilicone adjuvant }\end{array}$ & Repeat first year, applied Oct. \\
\hline 9 & CTH-Dec & Dec & $\begin{array}{l}1125 \mathrm{~g} \mathrm{ha}^{-1} \text { b} \text { clopyralid, } 225 \mathrm{~g} \mathrm{ha}^{-1} \text { ctriclopyr, } \\
150 \mathrm{~g} \mathrm{ha}^{-1} \text { dhaloxyfop, organosilicone adjuvant }\end{array}$ & No weed control. \\
\hline 10 & Winter Glyphosate & July & no weed control & $3000 \mathrm{~g} \mathrm{ha}^{-1}$ eglyphosate and organosilicone adjuvant \\
\hline 11 & $\begin{array}{l}\text { CTH-Oct and } \\
\text { Winter Glyphosate }\end{array}$ & Oct/July & $\begin{array}{l}1125 \mathrm{~g} \mathrm{ha}^{-1} \text { b clopyralid, } 225 \mathrm{~g} \mathrm{ha}^{-1} \text { criclopyr, } \\
150 \mathrm{~g} \mathrm{ha}^{-1} \text { dhaloxyfop, organosilicone adjuvant }\end{array}$ & $3000 \mathrm{~g} \mathrm{ha}^{-1}$ e glyphosate and organosilicone adjuvant \\
\hline $12^{*}$ & Spot Control (3) & Oct & $\begin{array}{l}\text { 1.4 diameter spot } 175 \mathrm{~g} \mathrm{ha}^{-1}{ }^{\mathrm{b}} \text { clopyralid, } 35 \mathrm{~g} \\
\mathrm{ha}^{-1} \mathrm{c}_{\text {triclopyr, organosilicone adjuvant }}\end{array}$ & $\begin{array}{l}1500 \mathrm{~g} \mathrm{ha}^{-1} \text { b clopyralid, } 300 \mathrm{~g} \mathrm{ha}^{-1} \text { ctriclopyr, } \\
\text { organosilicone adjuvant applied Oct. }\end{array}$ \\
\hline
\end{tabular}

${ }^{a}$ AGPRO Terbuthylazine 500, $500 \mathrm{~g} \mathrm{~L}^{-1}$ terbuthylazine, AGPRO NZ Ltd

bVersatill, $300 \mathrm{~g} \mathrm{~L}^{-1}$ clopyralid, DOW AgroSciences NZ

'Grazon, $600 \mathrm{~g} \mathrm{~L} \mathrm{~L}^{-1}$ triclopyr, DOW AgroSciences NZ

${ }^{\mathrm{d} G a l l a n t,} 100 \mathrm{~g} \mathrm{~L}^{-1}$ haloxyfop P-methyl, DOW AgroSciences NZ

${ }^{e}$ AGPRO Green Glyphosate 510, $510 \mathrm{~g} \mathrm{~L}^{-1}$ glyphosate, AGPRO NZ Ltd

$$
V=\frac{2 \cdot \pi \cdot \mathrm{gld}^{2} \cdot \mathrm{ht}}{15}
$$

At the final measurement date, average stand volume (SV: $\mathrm{m}^{3} \mathrm{ha}^{-1}$ ) was calculated as the average tree volume $(V)$ per treatment scaled to a hectare (1000 stems per hectare). In addition to this a total volume response was calculated for each treatment relative to the control, after first subtracting volume at initial measurement. Total volume (TV) response incorporates tree mortality, whereas SV does not, being the mean volume of all live trees.

Measurements of weeds were taken within a circle of 1$\mathrm{m}$ radius around each tree. The 1-m circle was subdivided into four quadrants centred around the tree and the height of the tallest weed in each quadrant was recorded. These four values were averaged to determine the mean maximum weed height $\left(A v_{-} h t\right)$. The percentage weed cover within each quadrant was estimated $\left(A v_{-} c o v\right)$ and the proportion of cover in broadly described functional weed types identified: (1) grasses, (2) herbaceous annuals (HBL) and (3) scrub weeds (C. scoparius, $U$. europaeus, $R$. fruticosus, Leycesteria formosa Wall. (Himalayan honeysuckle) and native woody plants).

Treatment costs were calculated using current information on application and product costs supplied by three forest management companies and taking an average of these. These costs were used to estimate the cost of each operation applied and a total cost for each treatment.

\section{Statistical analyses}

Linear mixed effects models were applied to examine relationships between herbicide treatment and either treeor weed-growth characteristics at specific dates following herbicide treatment. The dependent variables in the analyses were tree volume $(V)$; or weed cover $\left(A v_{-} c o v\right)$; the independent variable was treatment, with replicate plot included in the model as a random effect. Response variables ( $V$ and $A v_{-}$cov) were transformed using natural logarithms or square roots, respectively, to meet assumptions of normality and homogeneity of variance. Note that stand volume (SV) can be obtained from tree volume estimates by scaling to a hectare. Models were fitted with and without multiple variances, and 
comparisons were made with the Akaike Information Criterion (Akaike 1974) to select the optimal model. The mixed effects models were fitted using the REML method (Searle et al., 1992), with the complete weed control treatment (treatment 2: weed-free) used as the reference level. All modelling was performed using $R(R$ Core Team 2013). Tukey's “Honest Significant Difference" method was used for comparisons of treatment means where the overall model indicated significant difference between treatments. A summary of the key analyses are shown in the Appendix. Differences were considered significant at the $95 \%$ level (alpha $=0.05$ ).

\section{Results}

\section{Pinus radiata trial}

\section{Weed assessments}

Six months (190 days) after trial initiation, the percentage weed cover in the 1-m radius around each tree was low (mean $=3.6 \%$ ) except where oversowing had been carried out in the autumn before planting, combined with no follow-up control of the grasses (treatments 10 and 11: spot control 3 and spot control 4) (data not shown). In spot control 3 and spot control 4, grass cover was $80 \%$ or greater, dominated by $H$. lanatus. Emergence of scrub weeds at this stage, particularly C. scoparius and $U$. europaeus, and other competitive vegetation, was low in the no control treatment ( $20 \%$ cover) and across the site.

Growth of competitive vegetation over the second season after planting (between 6 and 18 months after trial initiation) increased significantly, with scrub weeds (predominantly C. scoparius) and grasses (predominantly H. lanatus) emerging as the dominant vegetation types (Fig. 1: no control treatment). The height of the tallest weeds in the no control treatment was $1.75 \mathrm{~m}, 10 \%$ taller than the average tree in this treatment. There was a high cover of competitive vegetation, particularly grasses, where oversowing had been carried out (Fig. 1, spot control treatments 3, 4 and 5). The highest cover of vegetation $(>80 \%)$ within a 1 -m radius of the tree occurred in the oversown plots where no treatment effective for grasses was applied (spot control 3 and 4). Cover in these treatments was significantly higher than that in any other treatment. This was followed by the no control and spot control 5 treatments where cover was 65 and $59 \%$, respectively. Cover of competitive vegetation was lowest in the weed-free control (3\%) where continuous, complete weed control was implemented. Cover of vegetation in the weed-free control was significantly lower than all other treatments barring CTH Oct x2 (9\%). The cover of vegetation in spot control 2, CTH-Dec x2, CTH-Oct, $\mathrm{CTH}-\mathrm{Dec}$ and spot control 1 was not significantly different from cover in the operational treatment (Fig. 1). Significant treatment comparisons are summarised for mean weed cover at 18 months (Table 3), with the spring application of herbicides resulting in significantly lower vegetation cover.

\section{Tree mortality and growth}

Mortality for the trial was low ( $<3 \%$ at 2.5 years). There were no significant differences $(P=0.36)$ in tree volume $(V)$ across treatments prior to trial initiation. At 2.5 years after trial initiation, significant differences in stand volume, between treatments and the controls were detected (Table 4).

Stand volume in the CTH-Oct $\mathrm{x} 2$, spot control 2 and spot control 5 treatments were amongst the highest and not significantly different from either the weed-free control, or operational treatment (Table 4). All of these treatments are, therefore, potentially viable alternatives to current operational treatments for this site. The most notable outcome for this trial is that the highest stand volume overall occurred in the CTH-Oct $\mathrm{x} 2$ treatment, as this treatment did not include any persistent herbicides. The second notable outcome is the high stand volume in the treatments spot control 2 and spot control 5. Both of these treatments included a spot application of terbuthylazine and hexazinone in year 1 followed by a broadcast herbicide treatment targeting the scrub weeds $C$. scoparius and $U$. europaeus in the spring after planting (Table 1). Spot control 2 and spot control 5 were identical in application of active ingredients and differed only in that spot control 5 included over-sowing with grass prior to planting, resulting in an overall higher cover of grasses (Fig. 1). Significant treatment comparisons are summarised for stand volume at 2.5 years (Table 5), with spring application of herbicides resulting in significantly higher stand volume.

Tree volume responses relative to the weed-free control are shown in Fig. 2. Initially there were positive treatment responses, particularly for spot control 5 , but these responses declined over time and, by 2.5 years, the volume response of spot control 5 fell below that of the weed-free control. Spot control 2 had a similar volume response at 2.5 years. The CTH-Oct $\mathrm{x} 2$ treatment showed a small positive volume response at 2.5 years, and that of the operational treatment was similar to the weed-free control. The results at 2.5 years were consistent with those for mean stand volume (SV) noted above.

\section{Treatment costs}

The estimated costs for each treatment (Table 6) allowed for a comparison of tree performance at 2.5 years as a function of treatment cost (Table 7). For example, a grower wanting to minimise costs, whilst accepting a moderate level of growth loss relative to the possible optimum, might choose something equivalent to either spot control 1 or CTH-Oct. A grower wanting to optimise growth whilst accepting a higher cost of weed control, might choose treatments equivalent to spot control 2, operational, $\mathrm{CTH}$ Oct $\mathrm{x} 2$ or spot control 5 . These analyses show that there is no low cost treatment with optimal growth. 


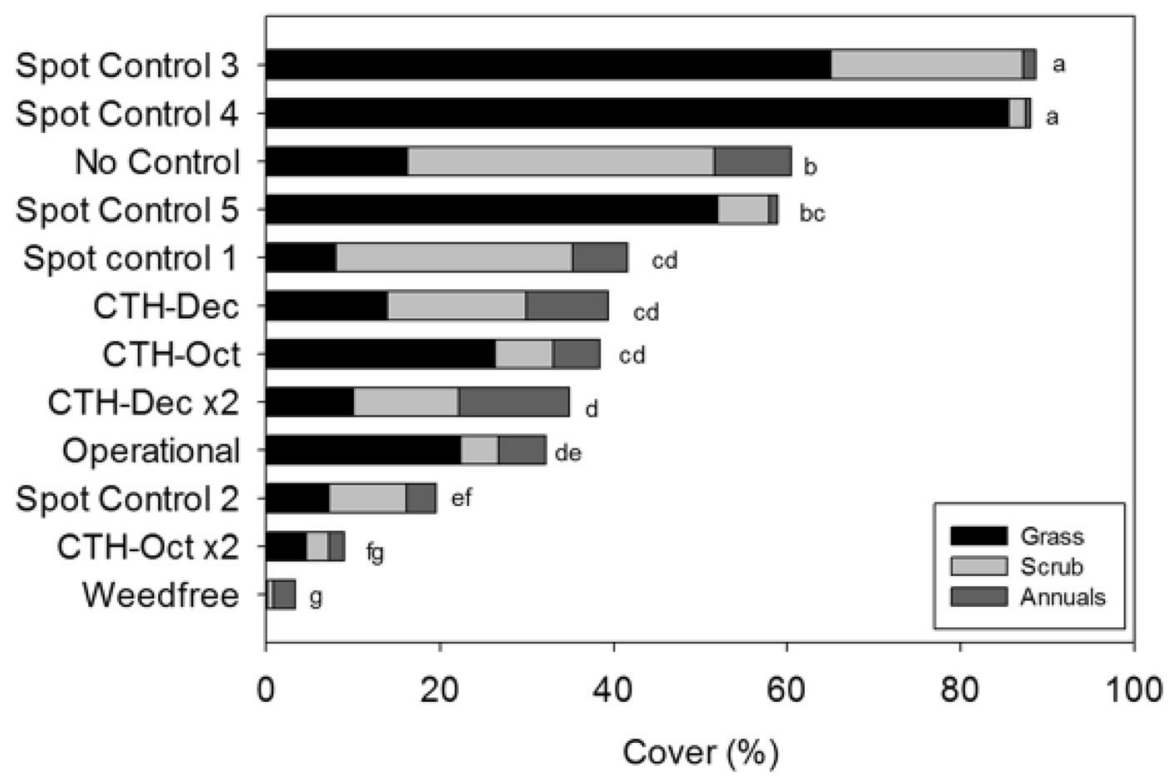

Fig. 1 Percentage weed cover showing functional weed types at 18 months (603 days) after trial initiation in the Pinus radiata trial. Treatment bars followed by the same letters are not significantly different in terms of total cover $(P>0.05)$. Details of the regression analyses are shown in the Appendix

\section{Pseudotsuga menziesii trial} Weed assessments

As with the Pinus radiata trial, at the end of the second season (18 months) the highest vegetation cover occurred in the oversown treatment, spot control 3 (95.6\% cover), followed by the no control treatment ( $80.3 \%$ cover) (Fig. 3 ). Cover in the no control treatment was predominantly $C$. scoparius, followed by grasses. The average height of the tallest weeds in the no control treatment at 18 months was $1.95 \mathrm{~m}, 99 \%$ taller than the height of the average tree. The lowest cover of vegetation occurred in the weed-free control $(9.5 \%$ cover $)$, which was significantly lower than all other treatments, with the exception of the CTH-Oct x2 treatment (Fig. 3). Cover of vegetation for the two treatments that included an application of glyphosate over the winter period (treatments 10 and 11: winter glyphosate and CTH-Oct and winter glyphosate) and spot control 2 was not significantly different from that in the operational standard (Fig. 3). However, this cover was significantly higher than that in the weed-free control. Significant treatment comparisons are summarised for

Table 3 Comparisons between treatments for weed cover (\%) within a 1-m radius centred around each tree for the Pinus radiata trial

\begin{tabular}{|c|c|c|c|}
\hline Treatment comparisons & Difference in cover (\%) & $P$ value & Result \\
\hline $\begin{array}{l}\text { CTH-Oct vs CTH-Oct x2 } \\
\text { (treatment } 6 \text { vs treatment 7) }\end{array}$ & 31.4 & $<0.001$ & $\begin{array}{l}\text { Cover of weeds (\%) significantly higher in plots } \\
\text { where a broadcast treatment was applied only } \\
\text { in spring after planting as opposed to spring } \\
\text { of planting and following year }\end{array}$ \\
\hline $\begin{array}{l}\text { CTH-Dec vs CTH-Dec x2 } \\
\text { (treatment } 8 \text { vs treatment 9) }\end{array}$ & -12.6 & 0.99 & $\begin{array}{l}\text { No significant difference in weed cover regardless } \\
\text { of frequency when release carried out in summer } \\
\text { (December) }\end{array}$ \\
\hline $\begin{array}{l}\text { CTH-Dec } \times 2 \text { vs CTH-Oct x2 } \\
\text { (treatment } 8 \text { vs treatment 6) }\end{array}$ & 26.1 & $<0.001$ & $\begin{array}{l}\text { Significantly higher cover of weeds at } 18 \text { months } \\
\text { where release carried out in summer (December) of planting } \\
\text { and following year versus spring (October) of both }\end{array}$ \\
\hline $\begin{array}{l}\text { Spot control } 2 \text { vs spot control } 1 \\
\text { (treatment } 5 \text { vs treatment } 4 \text { ) }\end{array}$ & -22.0 & $<0.001$ & $\begin{array}{l}\text { Cover of weeds (\%) significantly lower in spot } \\
\text { control } 2 \text { where an additional release operation } \\
\text { was carried out in the spring of the year after } \\
\text { planting }\end{array}$ \\
\hline $\begin{array}{l}\text { Spot control } 3 \text { vs Operational } \\
\text { (treatment } 12 \text { vs treatment } 3 \text { ) }\end{array}$ & 22.8 & $<0.001$ & $\begin{array}{l}\text { Significantly higher cover of weeds where } \\
\text { terbuthylazine and hexazinone applied as a 1.4-m } \\
\text { diameter spot in spring of planting as opposed to } \\
\text { an aerial application of same active ingredients }\end{array}$ \\
\hline
\end{tabular}


Table 4 Treatment means (and standard errors) for groundline diameter (gld), total tree height (ht), and stand volume (SV; determined as average tree volume scaled to a hectare) at 2.5 years

\begin{tabular}{|c|c|c|c|c|c|c|c|}
\hline \multirow[t]{3}{*}{ No } & \multirow[t]{3}{*}{ Treatment } & \multicolumn{3}{|c|}{ Pinus radiata } & \multicolumn{3}{|c|}{ Pseudotsuga menziesii } \\
\hline & & gld & ht & SV & gld & ht & SV \\
\hline & & $(\mathrm{mm})$ & $(\mathrm{m})$ & $\left(\mathrm{m}^{3} \mathrm{ha}^{-1}\right)$ & $(\mathrm{mm})$ & (m) & $\left(\mathrm{m}^{3} \mathrm{ha}^{-1}\right)$ \\
\hline 1 & No control & $43(3)$ & $2.8(0.1)$ & $3.0(0.5) d$ & $19(1)$ & $1.4(0.1)$ & $0.3(0.1) a$ \\
\hline 2 & Weed-free control & $69(3)$ & $2.5(0.1)$ & $5.6(0.6) a b c$ & $33(3)$ & $1.4(0.1)$ & $1.1(0.2) \mathrm{a}$ \\
\hline 3 & Operational & $66(2)$ & $2.8(0.1)$ & $5.4(0.5) a b$ & $31(2)$ & $1.5(0.1)$ & $0.9(0.2) a$ \\
\hline 4 & Spot control 1 & $51(2)$ & $2.8(0.1)$ & $3.4(0.3)$ abcd & $22(1)$ & $1.6(0.1)$ & $0.5(0.1) \mathrm{a}$ \\
\hline 5 & Spot control 2 & $61(2)$ & $3.0(0.1)$ & $4.9(0.3) a b c$ & $27(2)$ & $1.6(0.1)$ & $0.6(0.1) \mathrm{a}$ \\
\hline 6 & $\mathrm{CTH}-\mathrm{Oct} \times 2$ & $69(3)$ & $2.7(0.1)$ & $6.0(0.5)$ a & $29(2)$ & $1.4(0.1)$ & $0.8(0.1) \mathrm{a}$ \\
\hline 7 & CTH-Oct & $53(3)$ & $2.5(0.1)$ & $3.6(0.4) \mathrm{cd}$ & $25(2)$ & $1.6(0.1)$ & $0.5(0.1) \mathrm{a}$ \\
\hline 8 & CTH-Dec x2 & $54(3)$ & $2.6(0.1)$ & $3.7(0.4)$ abcd & $24(2)$ & $1.6(0.1)$ & $0.6(0.1) \mathrm{a}$ \\
\hline 9 & CTH-Dec & $50(2)$ & $2.8(0.1)$ & $3.3(0.4) \mathrm{bcd}$ & $30(2)$ & $1.7(0.1)$ & $0.8(0.1) \mathrm{a}$ \\
\hline 10 & Spot control $3^{*}$ & $33(2)$ & $2.3(0.1)$ & $1.3(0.2) \mathrm{e}$ & & & \\
\hline 11 & Spot control $4^{*}$ & $36(2)$ & $1.9(0.1)$ & $1.3(0.2) \mathrm{e}$ & & & \\
\hline 12 & Spot control $5^{*}$ & $58(2)$ & $3.0(0.1)$ & $4.6(0.4) a b c$ & & & \\
\hline 10 & Winter glyphosate & & & & $29(2)$ & $1.7(0.1)$ & $0.7(0.1) \mathrm{a}$ \\
\hline 11 & CTH-Oct + winter glyphosate & & & & $28(2)$ & $1.4(0.1)$ & $0.6(0.1) \mathrm{a}$ \\
\hline 12 & Spot control $3^{*}$ & & & & $22(1)$ & $1.4(0.1)$ & $0.4(0.0) \mathrm{a}$ \\
\hline
\end{tabular}

Treatments with the same letters are not significantly different (refer to the Appendix for regression details)

Treatments with oversowing are marked with an asterisk

mean weed cover at 18 months (Table 8), and as with the Pinus radiata trial, spring application of herbicides resulted in significantly lower vegetation cover.

\section{Tree mortality and growth}

Until the final measurement at 2.5 years, the mean trial mortality was below $2 \%$. At 2.5 years, $>10 \%$ mortality was recorded in the CTH-DEC $\mathrm{x} 2, \mathrm{CTH}$-Oct and winter glyphosate and CTH-Oct treatments, with $43 \%$ in the no control treatment.

There were no significant differences in stand volume amongst treatments after 2.5 years (Table 4). However, stand volume was highest in the weed-free control followed closely by the operational treatment, CTH-Dec, $\mathrm{CTH}-$ Oct $\mathrm{x} 2$, winter glyphosate, CTH-Oct and winter glyphosate, and spot control 2. All alternative treatments resulted in stand volume loss relative to the weed-free control of 24, 29,33, 35, 43 and 43\%, respectively.

As with the Pinus radiata trial, the efficacy of the treatments using clopyralid, triclopyr and haloxyfop (treatments 6-9) in reducing competition from weeds, was significantly reduced when applied in summer (December) rather than in spring (October). For the spot control treatments, there was a $42 \%$ increase in stand volume at 2.5 years when

Table 5 Comparisons between treatments for stand volume $\left(\mathrm{m}^{3} \mathrm{ha}^{-1}\right)$, recorded 2.5 years after treatment application in the Pinus radiata trial

\begin{tabular}{|c|c|c|c|}
\hline Treatment comparisons & $\begin{array}{l}\text { Difference in stand } \\
\text { volume }\end{array}$ & $P$ value & Result \\
\hline $\begin{array}{l}\text { CTH-Oct vs } \mathrm{CTH}-\mathrm{Oct} \times 2 \\
\text { (treatment } 7 \text { vs treatment 6) }\end{array}$ & -2.40 & 0.001 & $\begin{array}{l}\text { Significantly lower volume where weed control was carried out in } \\
\text { October of year } 1 \text { compared with control over both years. } \\
\text { A } 66 \% \text { increase in volume where } 2 \text { years of control carried out. }\end{array}$ \\
\hline $\begin{array}{l}\text { CTH-Dec vs CTH-Dec } \times 2 \\
\text { (treatment } 9 \text { vs treatment } 8 \text { ) }\end{array}$ & -0.37 & 0.999 & $\begin{array}{l}\text { No significant difference in volume when weed control } \\
\text { is carried out in December. }\end{array}$ \\
\hline $\begin{array}{l}\text { CTH-Dec } \times 2 \text { vs CTH-Oct } \times 2 \\
\text { (treatment } 8 \text { vs treatment } 6 \text { ) }\end{array}$ & -2.33 & 0.003 & $\begin{array}{l}\text { Significantly lower volume (64\%) where weed control in } \\
\text { year } 1 \text { and year } 2 \text { carried out in December rather than October. }\end{array}$ \\
\hline $\begin{array}{l}\text { Spot control } 2 \text { vs spot control } 1 \\
\text { (treatment } 5 \text { vs treatment 4) }\end{array}$ & 1.45 & 0.283 & $\begin{array}{l}\text { This difference was not significant. However, volume in spot } \\
\text { control } 2 \text { treatment was } 42 \% \text { greater than that in spot control } 1 \text {, } \\
\text { indicating benefit of second year control. }\end{array}$ \\
\hline
\end{tabular}




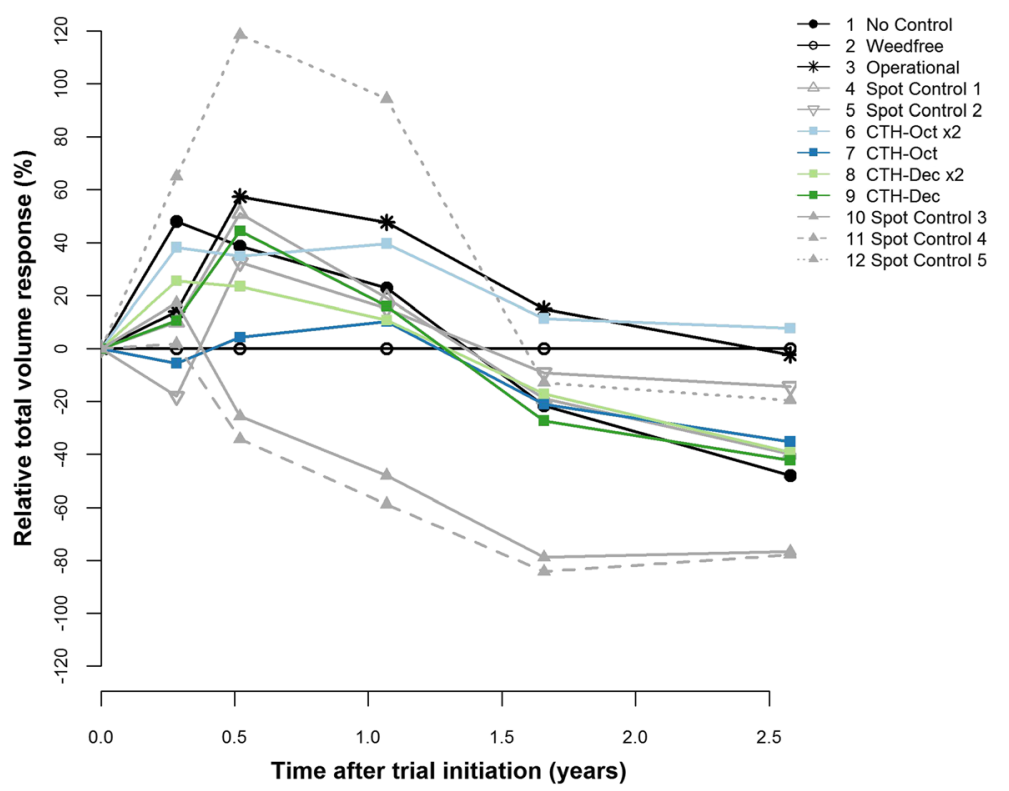

Fig. 2 Total tree volume response relative to that in the weed-free control in the Pinus radiata trial

Table 6 Estimation of treatment costs for the Pinus radiata and Pseudotsuga menziesii trials (excluding pre-plant spray with assumptions detailed below the table)

\begin{tabular}{llll}
\hline \multirow{2}{*}{ No } & Treatment & \multicolumn{2}{l}{ Trial } \\
\cline { 3 - 4 } 2 & Ninus radiata $(\$)$ & Pseudotsuga menziesii (\$) \\
\hline 1 & Weed-free control & 1056 & 0 \\
3 & Operational & 528 & 518 \\
4 & Spot control 1 & 205 & 205 \\
5 & Spot control 2 & 469 & 421 \\
6 & CTH-Oct x2 & 559 & 559 \\
7 & CTH-Oct & 279 & 279 \\
8 & CTH-Dec x2 & 559 & 559 \\
9 & CTH-Dec & 279 & 279 \\
10 & Spot control 3* & 300 & - \\
11 & Spot control 4* & 564 & - \\
12 & Spot control 5* & 569 & - \\
10 & Winter glyphosate & - & 139 \\
11 & CTH-Oct + glyphosate & - & 418 \\
12 & Spot control 3* & - & 464 \\
\hline
\end{tabular}

Treatments where oversowing was applied are marked with an asterisk. Aerial application: $\$ 100 \mathrm{ha}^{-1}$

Spot application $0.18 \mathrm{c}$ per tree (1000 stems per hectare)

Glyphosate product: $\$ 6.50 \mathrm{~L}^{-1}$

Terbuthylazine $\left(400 \mathrm{~g} \mathrm{~L}^{-1}\right)$ and hexazinone $\left(100 \mathrm{~g} \mathrm{~L}^{-1}\right)$ mix: $\$ 8.20 \mathrm{~L}^{-1}$

Clopyralid product $\left(300 \mathrm{~g} \mathrm{~L}^{-1}\right): \$ 30.00 \mathrm{~L}^{-1}$

Triclopyr product $\left(600 \mathrm{~g} \mathrm{~L}^{-1}\right): \$ 28.50 \mathrm{~L}^{-1}$

Haloxyfop product $\left(100 \mathrm{~g} \mathrm{~L}^{-1}\right): \$ 37.50 \mathrm{~L}^{-1}$

Terbuthylazine product $\left(500 \mathrm{~g} \mathrm{~L}^{-1}\right): \$ 5.60 \mathrm{~L}^{-1}$ weed control was also carried out in the year following planting (stand volume in spot control 1 vs spot control 2; Table 4).

Total tree volume responses over the trial period, relative to that in the weed-free control (treatment 2), were similar to those obtained for Pinus radiata (Fig. 4). Positive responses to most herbicide treatments were observed in the early stages of tree growth. However, at 2.5 years, total tree volume responses for the operational, spot control 2, CTH-Oct x2, CTH-Dec, and winter glyphosate treatments were $>20 \%$ less than that in the weed-free control.

\section{Treatment costs}

The estimated costs for each treatment (Table 6) allowed for a comparison of tree performance at 2.5 years as a function of treatment cost (Table 9). The two most cost- and operationally effective alternatives to current

Table 7 Ranking of tree performance against estimated total cost of release treatments for the Pinus radiata trial

\begin{tabular}{llll}
\hline $\begin{array}{l}\text { Volume loss (\%) } \\
\text { relative to weed-free } \\
\text { control treatment }\end{array}$ & $\begin{array}{l}\text { Low cost } \\
<\$ 300\end{array}$ & $\begin{array}{l}\text { Med cost } \\
\$ 300-600\end{array}$ & $\begin{array}{l}\text { High cost } \\
>\$ 600\end{array}$ \\
\hline 0 & & CTH-Oct $\times 2$ & $\begin{array}{l}\text { Weed-free } \\
\text { control }\end{array}$ \\
$1-20$ & & $\begin{array}{l}\text { Spot control 2 } \\
\text { Operational } \\
\text { Spot control 5 }\end{array}$ & \\
& & CTH-Dec $\times 2$ & \\
$21-40$ & Spot control 1 & & \\
& CTH-Oct & Spot control 4 & \\
& No control & & \\
& CTH-Dec & & \\
& Spot control 3 & & \\
\hline
\end{tabular}




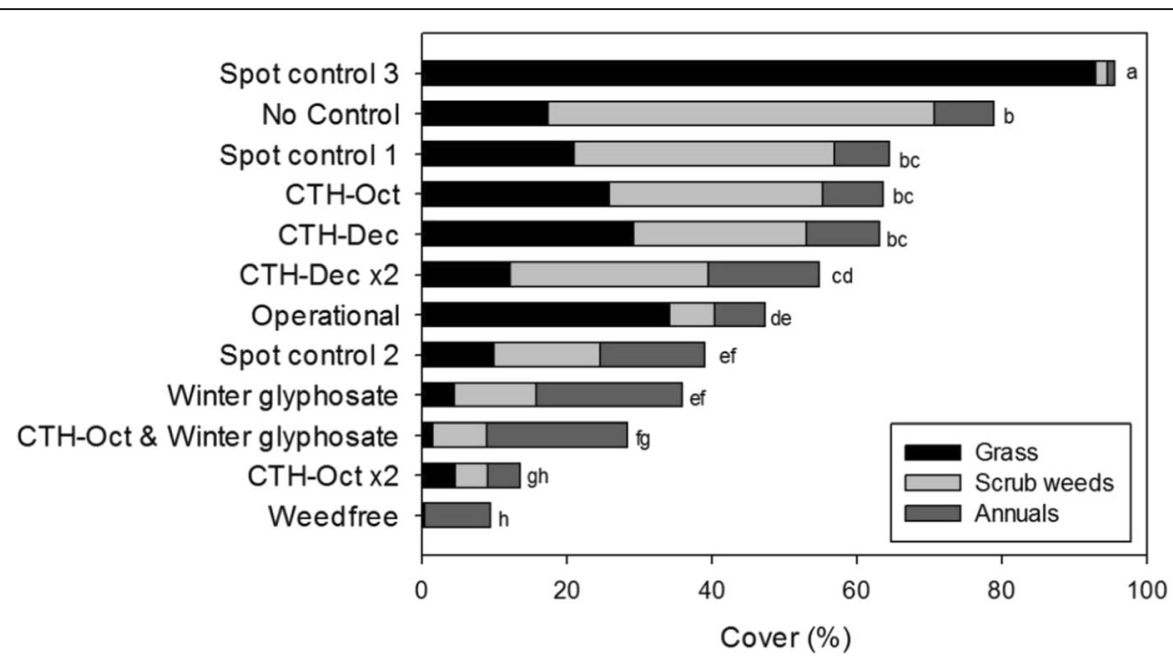

Fig. 3 Percentage weed cover showing functional weed types at 18 months (603 days) after trial initiation in the Pseudotsuga menziesii trial. Treatment bars followed by the same letters are not significantly different $(P>0.05)$. Results of analyses shown in the Appendix

practice are CTH-Oct $\mathrm{x} 2$ and winter glyphosate. The winter glyphosate treatment was approximately one quarter the cost of CTH-Oct x2 (NZD \$139 versus NZD \$559), although mean stand volume was very similar between these two alternatives $\left(0.76 \mathrm{~m}^{3} \mathrm{ha}^{-1}\right.$ vs $\left.0.73 \mathrm{~m}^{3} \mathrm{ha}^{-1}\right)$.

\section{Discussion and conclusions}

The results of the two trials show that some alternative treatments could be used either to replace terbuthylazine and hexazinone, or to reduce inputs during the first and second year of weed control, notably for sites dominated by $C$. scoparius. For the Pinus radiata trial, the treatments with the highest potential were either (i) an aerial application of $1125 \mathrm{~g} \mathrm{ha}^{-1}$ clopyralid, $225 \mathrm{~g} \mathrm{ha}^{-1}$ triclopyr and $150 \mathrm{~g} \mathrm{ha}^{-1}$ haloxyfop in the spring following planting, and the year after or (ii) spot control with $1200 \mathrm{~g} \mathrm{ha}^{-1}$ terbuthylazine and $300 \mathrm{~g} \mathrm{ha}^{-1}$ hexazinone in the spring following planting, followed by an aerial broadcast release with $1500 \mathrm{~g} \mathrm{ha}^{-1}$ clopyralid, $150 \mathrm{~g} \mathrm{ha}^{-1}$ triclopyr and $150 \mathrm{~g} \mathrm{ha}^{-1}$ haloxyfop in spring of year 2. This latter treatment can be also combined with oversowing. Watt and Rolando (2014) indicated that clopyralid, triclopyr and picloram could be used to manage
C. scoparius in young Pinus radiata stands. The results of the current trial indicate that effective control of C. scoparius and $U$. europaeus can also be achieved without the use of the active ingredient picloram. The results of the current study are also consistent with previous research by Tran et al. (2015). These authors showed clopyralid has a similar impact on C. scoparius germination and regrowth as the operational control used in this study.

General trends observed in the Pseudotsuga menziesii trial were similar to those in the Pinus radiata trial. For example, the CTH-Oct $\mathrm{x} 2$ and spot control 2 treatments were amongst the better performing alternatives to the current operational treatment. The application of glyphosate during winter was also a promising treatment for Pseudotsuga menziesii since this species is dormant over the winter phase during March to August (Maclaren 2008). Stand volume at 2.5 years in the winter glyphosate treatment was not significantly different from the weed-free control. Phytotoxic injury to Pseudotsuga menziesii in response to late season application of glyphosate has been observed in other studies (Harrington et al. 1995) so it is important to deploy this treatment early in winter.

Table 8 Comparisons between treatments for weed cover (\%) within a $1 \mathrm{~m}$ radius centred around each tree in the Pseudotsuga menziesii trial

\begin{tabular}{llll}
\hline Treatment comparisons & Difference in cover (\%) & $P$ value & Comment \\
\hline $\begin{array}{l}\text { Spot control } 2 \text { vs spot control 1 } \\
\text { (treatment } 5 \text { vs treatment 4) }\end{array}$ & -26 & $<0.001$ & $\begin{array}{l}\text { Cover significantly lower in spot control } 2 \text { where a } \\
\text { second year control operation was carried out }\end{array}$ \\
$\begin{array}{l}\text { CTH-Oct vs CTH-Oct x2 } \\
\text { (treatment 7 vs treatment 6) }\end{array}$ & 48.7 & $<0.001$ & $\begin{array}{l}\text { Cover significantly higher in plots where a broadcast } \\
\text { treatment was applied only in October of year } 1 \text { as } \\
\text { opposed to year 1 and year } 2\end{array}$ \\
$\begin{array}{l}\text { CTH-Dec x 2 vs CTH-Oct x2 } \\
\text { (treatment } 8 \text { vs treatment 6) }\end{array}$ & 38.2 & $\begin{array}{l}\text { Cover significantly higher where control was carried } \\
\text { out in December rather than October indicating the } \\
\text { benefit of early weed control }\end{array}$
\end{tabular}

The difference in cover (\%) between the treatments, using the second treatment as the base, the significance of the comparison and its meaning are described in the table 


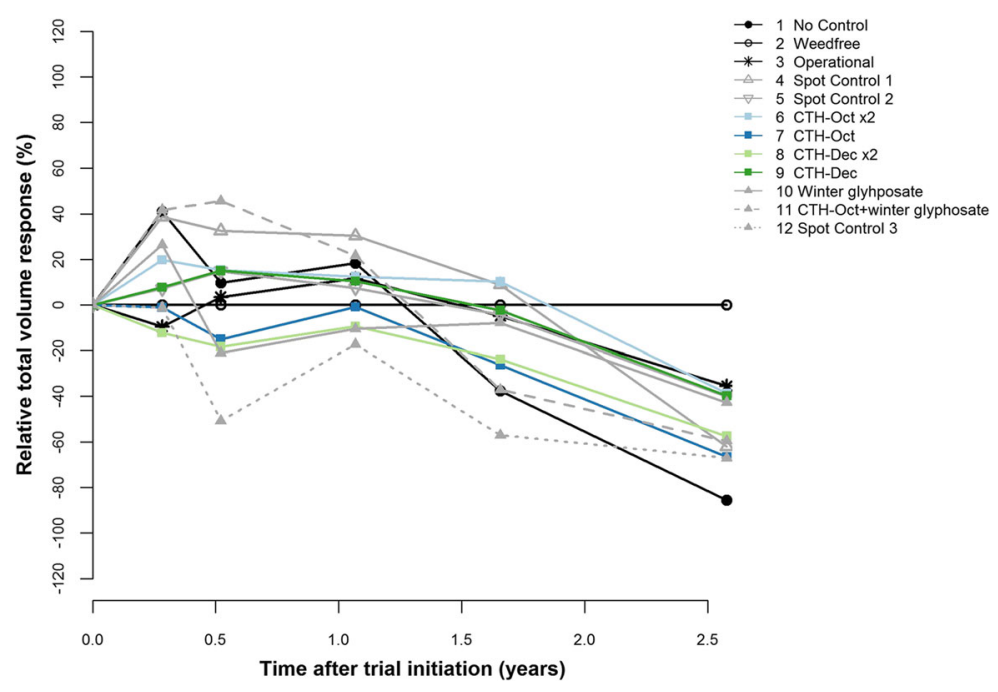

Fig. 4 Total tree volume response relative to that in the weed-free control in the Pseudotsuga menziesii trial

Tree volume differed with timing (October versus December) and frequency (1 year versus 2 years) of application of clopyralid, triclopyr and haloxyfop (treatments 6-9 both trials). This result highlighted the benefits that can be gained (in terms of reduced weed cover or greater tree volume) from repeated application of these herbicides early in the growing season. For the Pinus radiata trial, repeated application in spring amounted to a $66 \%$ increase in mean stand volume at 2.5 years after trial initiation over that where only one application was made, with a corresponding $40 \%$ increase for the Pseudotsuga menziesii trial. Repeated application in spring (October) rather than summer (December) resulted in a $64 \%$ increase in stand volume for the Pinus radiata trial and 36\% for the Pseudotsuga menziesii trial. Highest efficacy is likely to be achieved when weeds are below $10 \mathrm{~cm}$ and actively growing since all of these active ingredients are systemic and foliar active, with little residual activity (Tomlin 2015). Similar results have been previously found for Pinus radiata growing in competition with C. scoparius (Watt and Rolando 2014).

Table 9 Ranking of tree performance against estimated total cost of release treatments for the Pseudotsuga menziesii trial

\begin{tabular}{llll}
\hline $\begin{array}{l}\text { Volume loss (\%) } \\
\text { relative to weed-free } \\
\text { control treatment }\end{array}$ & $\begin{array}{l}\text { Low cost } \\
<\$ 300\end{array}$ & $\begin{array}{l}\text { Med cost } \\
\$ 300-600\end{array}$ & $\begin{array}{l}\text { High cost } \\
>600\end{array}$ \\
\hline 0 & & & $\begin{array}{l}\text { Weed-free } \\
\text { control }\end{array}$ \\
$1-20$ & & \\
$21-40$ & Winter glyphosate & Operational & \\
& CTH-Dec & CTH-Oct $\times 2$ & \\
$>40$ & No control & Spot control 2 & \\
& Spot control 1 & CTH-Oct + winter & glyphosate \\
& CTH-Oct & Spot control 3 & \\
& & CTH-Dec $\times 2$ & \\
& &
\end{tabular}

The objective of oversowing is to occupy the site with an easy-to-manage cover crop soon after harvesting, before the more competitive scrub weeds establish. Oversowing with $H$. lanatus in this experiment, increased cover of competitive vegetation overall and reduced the relative cover of $C$. scoparius at 18 months. However, for the treatments spot control 3 and spot control 4 in the Pinus radiata trial, the high cover of grasses during the first 18 months after trial initiation resulted in a $77 \%$ growth loss in stand volume at 2.5 years. The inclusion of a selective grass herbicide, such as haloxyfop, into these treatments could have provided control of the grasses in the 1.4-m spot around the trees. Some control of the grasses in the 1.4-m spot around the trees was provided in the spring after planting by the terbuthylazine and hexazinone mix used in spot control 5 (data not shown). This treatment was identical to spot control 2, with the exception of the oversowing in plots where spot control 5 was applied. There was no significant difference in stand volume for spot control 2 and spot control 5 at 2.5 years; however, the spectrum of competitive vegetation had shifted to one dominated by grasses in the latter treatment.

Few of the alternative treatments tested in these trials resulted in significant growth loss to trees relative to the current operational standard. Using estimated costs, none of the above treatments significantly increased costs over and above that for the operational standard treatment. It is recommended that further trialling of these treatments takes place on individual sites before they are deployed at an operational scale.

\section{Endnotes}

${ }^{1}$ Terbuthylazine: $\mathrm{N}^{2}$-tert-butyl-6-chloro-N4-ethyl-1,3,5triazine-2,4-diamine;

Hexazinone: 3-cyclohexyl-6-dimethylamino-1-methyl-1, 3,5-triazine-2,4- $(1 \mathrm{H}, 3 \mathrm{H})$-dione; 
Triclopyr: 3,5,6-trichloro-2-pyridyloxyacteic acid; Clopyralid: 3,6-dichloropyridine-2-carboxylic acid; Haloxyfop: methyl (R)-2-[4-(3-chloro-5-(trifluoromethyl)2-pyridyloxy)phenoxy]propionic acid;

Picloram: 4-amino-3,5,6-trichloropyridine-2-carboxylic acid; Indaziflam: $\mathrm{N}-[(1 \mathrm{R}, 2 \mathrm{~S})-2,3-$ dihydro-2,6-dimethyl-1H-inden1-yl]-6-[(1RS)-1-fluorothyl]-1,3,5-triazine-2,4-diamine;

Nicosulfuran: $8=2$-(4,6-dimethoxypyrmidin-2-ylcarbamoylsulfamoyl)-N,N-dimethylnicotinamide;

Mesotrione: 2-(4-mesyl-2-nitobenzoyl)cyclohexane-1,3dione.

\section{Appendix}

Summary of the regression analysis for (the square root transformation of) weed cover at 18 months (603 days) after trial initiation and the (natural logarithmic transformation of) tree volume, (ln) at (2.5) years after trial initiation.

\begin{tabular}{|c|c|c|c|c|c|c|c|c|}
\hline \multirow[t]{2}{*}{ Parameter } & Value & SE & DF & $P$ value & Value & SE & DF & $P$ value \\
\hline & \multicolumn{4}{|c|}{ Pinus radiata } & \multicolumn{4}{|c|}{ Pseudotsuga menziesii } \\
\hline \multicolumn{9}{|c|}{ (square root) Cover at 605 days } \\
\hline (Intercept) & 1.41 & 0.77 & 425 & 0.000 & 2.86 & 0.72 & 373 & 0.000 \\
\hline Treat1 & 6.49 & 1.08 & 36 & 0.000 & 6.05 & 1.02 & 36 & 0.000 \\
\hline Treat3 & 3.75 & 1.09 & 36 & 0.001 & 3.52 & 1.04 & 36 & 0.002 \\
\hline eat4 & 4.89 & 1.09 & 36 & 0.000 & 5.22 & 1.03 & 36 & 0.000 \\
\hline Treat5 & 2.98 & 1.09 & 36 & 0.009 & 3.27 & 1.03 & 36 & 0.003 \\
\hline reat6 & 2.20 & 1.08 & 36 & 0.049 & 1.45 & 1.03 & 36 & 0.169 \\
\hline Treat7 & 5.11 & 1.09 & 36 & 0.000 & 5.41 & 1.03 & 36 & 0.000 \\
\hline reat8 & 4.45 & 1.10 & 36 & 0.000 & 4.61 & 1.03 & 36 & 0.000 \\
\hline Treat9 & 4.94 & 1.09 & 36 & 0.000 & 5.15 & 1.03 & 36 & 0.000 \\
\hline Treat $10^{\mathrm{a}}$ & 7.99 & 1.08 & 36 & 0.000 & 3.06 & 1.03 & 36 & 0.005 \\
\hline Treat11 ${ }^{\mathrm{a}}$ & 7.96 & 1.08 & 36 & 0.000 & 2.43 & 1.05 & 36 & 0.026 \\
\hline Treat12 ${ }^{\mathrm{a}}$ & 6.14 & 1.10 & 36 & 0.000 & 6.91 & 1.01 & 36 & 0.000 \\
\hline \multicolumn{9}{|c|}{ (In) Volume at 941 days } \\
\hline (Intercept) & -5.44 & 0.15 & 421 & 0.000 & -7.97 & 0.42 & 319 & 0.000 \\
\hline Treat1 & -0.92 & 0.27 & 36 & 0.002 & -0.83 & 0.54 & 36 & 0.133 \\
\hline Treat3 & 0.08 & 0.20 & 36 & 0.689 & 0.40 & 0.57 & 36 & 0.491 \\
\hline Treat4 & -0.49 & 0.23 & 36 & 0.036 & -0.29 & 0.54 & 36 & 0.593 \\
\hline Treat5 & 0.01 & 0.20 & 36 & 0.943 & 0.15 & 0.54 & 36 & 0.778 \\
\hline Treat6 & 0.12 & 0.22 & 36 & 0.602 & 0.02 & 0.57 & 36 & 0.971 \\
\hline Treat7 & -0.59 & 0.26 & 36 & 0.028 & 0.03 & 0.56 & 36 & 0.957 \\
\hline Treat8 & -0.51 & 0.24 & 36 & 0.038 & 0.08 & 0.55 & 36 & 0.886 \\
\hline Treat9 & -0.54 & 0.23 & 36 & 0.023 & 0.34 & 0.53 & 36 & 0.533 \\
\hline Treat10 & -1.58 & 0.23 & 36 & 0.000 & 0.35 & 0.54 & 36 & 0.516 \\
\hline Treat11 & -1.66 & 0.26 & 36 & 0.000 & -0.08 & 0.58 & 36 & 0.893 \\
\hline Treat12 & -0.11 & 0.21 & 36 & 0.606 & -0.38 & 0.54 & 36 & 0.482 \\
\hline
\end{tabular}

The intercept represents the weed-free control

${ }^{a}$ Treatments 10, 11 and 12 were different for the two trials

\section{Acknowledgements}

The authors would like to acknowledge Rayonier/Matariki Forests for their support with the management and maintenance of this trial and for making their land available for trial purposes. We would also like to acknowledge the Forest Owners Association for their contribution of funding towards this project between 2011 and 2014.

\section{Authors' contributions}

CR and MW developed the concept for this trial together with Rayonier/ Matariki Forests and were responsible for its design and implementation. C analysed the data and prepared figures and tables for this manuscript. $\mathrm{DH}$ and $\mathrm{AL}$ were the senior technical field staff responsible for the implementation and assessments on the trial. All authors contributed to the preparation and review of the manuscript.

\section{Competing interests}

The authors declare that they have no competing interests.

\section{Author details}

${ }^{1}$ Scion, PO Box 3020, Rotorua, New Zealand. ${ }^{2}$ Scion, PO Box 29237, Fendalton, Christchurch, New Zealand.

Received: 10 March 2016 Accepted: 29 October 2016

Published online: 20 January 2017

\section{References}

Akaike, H. (1974). New look at statistical model identification. IEEE Transactions on Automatic Control, 19(6), 716-723.

Baillie, B. R. (2016). Herbicide concentrations in waterways following aerial application in a steepland planted forest in New Zealand. New Zealand Journal of Forestry Science, 46, 16.

Campbell, T. N., Jones, P. D., Ezell, A. W., \& Demarais, S. (2013). Growth and competition response in intensively established loblolly pine plantations at crown closure. Journal of Forestry, 111(5), 313-318.

Eccles, N. S., Kritzinger, J. L., \& Little, K. (1997). Appropriateness of non-destructive measures of pine tree performance in weeding experiments. South African Journal of Forestry, 178, 25-29.

Forest Owners Association. (2014). 2014 facts and figures. Wellington, New Zealand: New Zealand Forest Owners Association Inc.

Forest Stewardship Council. (2007). FSC pesticide policy: guidance on implementation. Bonn: Forest Stewardship Council.

Forest Stewardship Council. (2015). Indicators and thresholds for the identification of 'highly hazardous' pesticides (HHP) (FSC International Center: Policy and Standards Unit). Bonn: Forest Stewardship Council.

Garrett, L. G., Watt, M. S., \& Pearce, S. H. (2016). Environmental fate of terbuthylazine and hexazinone in a planted forest steepland Recent Soil, New Zealand. New Zealand Journal of Forestry Science, 46: 17.

Harrington, T. B., Wagner, R. G., Radosevich, S. R., \& Walstad, J. D. (1995). Interspecific competition and herbicide injury influence 10-year responses of coastal Douglas-fir and associated vegetation to release treatments. Forest Ecology and Management, 76(1-3), 55-67. doi:10.1016/0378-1127(95)03558-R.

Little, K. M., \& Rolando, C. A. (2002). Post-establishment vegetation control in a Eucalyptus X E. camaldulensis stand. South African Forestry Journal, 193, 77-80.

Little, K., Willoughby, I., Wagner, R., Adamas, P., Frochet, H., Gava, J., Gous, S., Lautenschlager, R., Orlander, G., Sankaran, K., \& Wei, R. (2006). Towards reduced herbicide use in forest vegetation management. Southern African Forestry Journal, 207, 63-79.

Maclaren, J. P. (2008). Douglas fir growers manual. Rotorua: Scion.

McCarthy, N, Bentsen, NS, Willoughby, I, \& Balandier, P (2011). The state of forest vegetation management in Europe in the 21 st century. European Journal of Forest Research, 130, 7-16. doi:10.007/s10342-101-0429-5

Mendell, B. C., Lang, A. H., Caldwell, W., \& Garrett, D. L. (2015). Chemical use and forest certification: productivity and economic implications. Journal of Forestry, 113(4), 367-371. doi:10.5849/jof.14-121.

Neary, D. G., \& Michael, J. L. (1996). Herbicides-protecting long-term sustainability and water quality in forest ecosystems. New Zealand Journal of Forest Science, 26(1-2), 241-263.

New Zealand Institute of Economic Research. (2015). How valuable is that plant species? NZIER report to the Ministry for Primary Industries. Wellington: New Zealand Institute of Economic Research. 
New Zealand Meteorological Service. (1983). Summaries of climatological observations to 1980 (No. 177). Wellington: New Zealand MetService.

R Core Team. (2013). R: A language and environment for statistical computing. Vienna: R Foundation for Statistical Computing.

Richardson, B. (1991). The effects of plant competition on growth of radiata pine. In M. I. Menzies, G. E. Parrot, \& L. Whitehouse (Eds.), Proceedings of the IUFRO Conference: Efficiency of stand establishment operations (pp. 242-249). Rotorua: New Zealand Forest Research Ltd.

Richardson, B. (1993). Vegetation management practices in plantation forests of Australia and New Zealand. Canadian Journal of Forest Research, 23, 1989-2005.

Richardson, B., Davenhill, N., Coker, G., Ray, J., Vanner, A., \& Kimberly, M. (1996). Optimising spot weed control: First approximation of the most cost effective spot size. New Zealand Journal of Forestry Science, 26, 265-275.

Richardson, B., Ray, J., Vanner, A., Davenhill, N., \& Miller, K. (1996). Nozzles for minimising aerial herbicide spray drift. New Zealand Journal of Forestry Science, 26(3), 438-448.

Rolando, C. A., \& Little, K. M. (2009). Regional vegetation management standards for commercial pine plantations in South Africa. Southern Forests, 71(3), 187-199.

Rolando, C. A., \& Watt, M. S. (2014). Herbicides for use in management of certified Pinus radiata plantations in New Zealand. Australian Forestry, 77(2), 123-132. doi:10.1080/00049158.2014.936656

Rolando, C., Zabkiewicz, J., \& Watt, M. (2010). A review of the vegetation management practices for the New Zealand forest sector and the cost implications for compliance to the FSC pesticide policy. Rotorua: New Zealand: New Zealand Forest Research Ltd.

Rolando, C. A., Gous, S. F., \& Watt, M. S. (2011). Preliminary screening of herbicide mixes for the control of five major weed species on certified Pinus radiata plantations in New Zealand. New Zealand Journal of Forestry Science, 41, 165-175.

Rolando, C. A., Garrett, L. G., Baillie, B. R., \& Watt, M. S. (2013). A survey of herbicide use and a review of environmental fate in New Zealand planted forests. New Zealand Journal of Forestry Science, 43: 17.

Searle, S. R., Casella, G., \& McCulloch, C. E. (1992). Variance components. New York: Wiley.

Thiffault, N., \& Roy, V. (2011). Living without herbicides in Québec (Canada): historical context, current strategy, research and challenges in forest vegetation management. European Journal of Forest Research, 130(1), 117-133. doi:10.1007/s10342-010-0373-4

Thompson, D. G., \& Pitt, D. G. (2003). A review of Canadian forest vegetation management research and practice. Annals of Forest Science, 60(7), 559-572.

Tomlin, C. (2015). The Pesticide Manual (Fourteen ed.). Hampshire: British Crop Protection Council.

Tran, H., Harrington, K. C., Robertson, A. W., \& Watt, M. S. (2015). Relative persistence of commonly used forestry herbicides for preventing the establishment of broom (Cytisus scoparius) seedlings in New Zealand plantations. New Zealand Journal of Forestry Science, 45, 6.

Wagner, R. G., Flynn, J., \& Gregory, R. (1998). Public perceptions of risk and acceptability of forest vegetation management alternatives in Ontario. Forestry Chronicle, 74(5), 720-727.

Wagner, R., Little, K., Richardson, B., \& McNabb, K. (2006). The role of vegetation management for enhancing the productivity of the worlds forest. Forestry, 79, 57-79.

Watson, M, Watt, MS, Withers, TM, Kimberly, M, \& Rolando, C (2010). Potential for Cleopus japonicus to control the weed Buddleja davidii in plantation forests in New Zealand. Forest Ecology and Management. doi:10.1016/j. foreco.2010.09.031

Watt, M. S., \& Rolando, C. A. (2014). Alternatives to hexazinone and terbuthylazine for chemical control of Cytisus scoparius in Pinus radiata plantations in New Zealand. Weed Research, 54(3), 265-273.

Watt, M., Wang, H., Rolando, C., Zaayman, M. \& Martin, K. (2010). Adsorption of the herbicide terbuthylazine across a range of New Zealand forestry soils. Canadian Journal of Forest Research, 40, 1448-1457.

Watt, M. S., Palmer, D. J., Kimberley, M. O., Höck, B. K., Payn, T. W., \& Lowe, D. J. (2010). Development of models to predict Pinus radiata productivity throughout New Zealand. Canadian Journal of Forest Research, 40(3), 488-499. doi:10.1139/X09-207.

\section{Submit your manuscript to a SpringerOpen ${ }^{\circ}$ journal and benefit from:}

- Convenient online submission

- Rigorous peer review

- Immediate publication on acceptance

- Open access: articles freely available online

- High visibility within the field

- Retaining the copyright to your article

Submit your next manuscript at $\gg$ springeropen.com 